\title{
Interleukin-3 prevents neuronal death induced by amyloid peptide Angara Zambrano ${ }^{1,2}$, Carola Otth ${ }^{1,2}$, Lorena Mujica ${ }^{1,2}$, Ilona I Concha*1 and Ricardo B Maccioni ${ }^{2}$
}

\author{
Address: ${ }^{1}$ Instituto de Bioquímica, Facultad de Ciencias, Universidad Austral de Chile, Chile and ${ }^{2}$ Laboratory of Cellular, Molecular Biology and \\ Neuroscience, Millennium Institute for Advanced Studies in Cell Biology and Biotechnology (CBB), Facultad de Ciencias, Universidad de Chile, \\ Chile \\ Email: Angara Zambrano - angarazambrano@uach.cl; Carola Otth - cotth@uach.cl; Lorena Mujica - lmujica@uach.cl; \\ Ilona I Concha* - conchagrabinger@uach.cl; Ricardo B Maccioni - rmaccion@uchile.cl \\ * Corresponding author
}

Published: 3 October 2007

BMC Neuroscience 2007, 8:82 doi:10.1 |86/147|-2202-8-82

Received: 17 January 2007

Accepted: 3 October 2007

This article is available from: http://www.biomedcentral.com/I47I-2202/8/82

(c) 2007 Zambrano et al.; licensee BioMed Central Ltd.

This is an Open Access article distributed under the terms of the Creative Commons Attribution License (http://creativecommons.org/licenses/by/2.0), which permits unrestricted use, distribution, and reproduction in any medium, provided the original work is properly cited.

\begin{abstract}
Background: Interleukin-3 (IL-3) is an important glycoprotein involved in regulating biological responses such as cell proliferation, survival and differentiation. Its effects are mediated via interaction with cell surface receptors. Several studies have demonstrated the expression of IL-3 in neurons and astrocytes of the hippocampus and cortices in normal mouse brain, suggesting a physiological role of IL-3 in the central nervous system. Although there is evidence indicating that IL-3 is expressed in some neuronal populations, its physiological role in these cells is poorly known.
\end{abstract}

Results: In this study, we demonstrated the expression of IL-3 receptor in cortical neurons, and analyzed its influence on amyloid $\beta$ (A $\beta$ )-treated cells. In these cells, IL-3 can activate at least three classical signalling pathways, Jak/STAT, Ras/MAP kinase and the PI 3-kinase. Viability assays indicated that IL-3 might play a neuroprotective role in cells treated with $A \beta$ fibrils. It is of interest to note that our results suggest that cell survival induced by IL-3 required PI 3-kinase and Jak/STAT pathway activation, but not MAP kinase. In addition, IL-3 induced an increase of the anti-apoptotic protein $\mathrm{Bcl}-2$.

Conclusion: Altogether these data strongly suggest that IL-3 neuroprotects neuronal cells against neurodegenerative agents like $A \beta$.

\section{Background}

The cytokine, Interleukin (IL)-3 is an important regulator which exhibits pleiotropic activities [1]. It is expressed in hematopoietic cells as well in several non-hematopoietic cell types [2-8]. The biological activity of IL-3 is mediated through specific cell surface receptors which are composed of $\alpha$ and $\beta$ subunits. The $\alpha$ subunit is responsible for the binding of IL-3. The ligand-activated $\alpha$ subunit is associated with the $\beta$ subunit, which transmits signals across the plasma membrane [9]. IL-3 is known to activate at least three signaling pathways: The Jak/STAT, the Ras/ Raf/mitogen-activated protein kinase, and the phosphatidylinositol 3-kinase (PI 3-kinase)/protein kinase B (PKB) pathway. An important PI 3-kinase target is the serine/ threonine kinase Akt/PKB, which, mediated by many growth factors [10] (Dudek et al., 1997), is involved in cell survival.

Several studies have demonstrated the presence of IL-3 in the central nervous system $[4,5,11]$. Although there is evi- 
dence indicating that IL-3 is expressed in some neuronal populations [12], its physiological role in these cells is unknown. Some studies [13] demonstrated that IL-3 significantly facilitates sensory neuron survival and stimulates the formation of the neural network in vitro, promotes the process extension of cultured cholinergic neurons [14], and that IL-3 exerts a trophic action on hippocampal neurons, rescuing hippocampal CA1 neurons from lethal ischemic damage [15]. However, the mechanism by which IL-3 supports neurons has not yet been determined.

In the nervous system and particularly during development, apoptosis appears to be triggered by trophic factor deprivation. Neuronal apoptosis is likely to occur in Alzheimer's disease (AD), a widespread neurodegenerative disorder that results in progressive dementia [16]. Histopathologically, AD is characterized by the presence of extracellular senile plaques that consist of $\beta$-amyloid protein $(A \beta)$ in its fibrillary form, and neurofibrillary tangles [17]. A $\beta$ causes hippocampal and cortical neuronal death in vitro and in vivo $[18,19]$. It has been suggested that $\mathrm{A} \beta_{1-40}$ and $\mathrm{A} \beta_{1-42}$ downregulate $\mathrm{BCl}-2$, and that this effect may lead to increased neuronal degeneration during agedependent stresses [20].

In this study, we provide direct evidence for the functional expression of IL-3 receptors on neurons. We also demonstrated their involvement in the neuroprotective action of IL-3 upon A $\beta$-neurotoxicity. We demonstrated that receptor activation signals cell survival in the presence of $A \beta$. Our results suggest that the effect of IL-3 on cortical neurons is mediated by activation of the Ser/Thr kinase Akt and kinase Jak, both important components of anti-apoptotic mechanisms in neurons and other cell types. And worthy of note, IL-3 was able to induce an increase in Bcl2 protein in these cells.

\section{Results}

Expression of functional IL-3 receptors in cortical neurons The expression of both $\alpha$ and $\beta$ subunits of IL-3 receptor in primary cortical neurons was confirmed using specific antibodies. Immunofluorescence analysis using anti-IL3r $\alpha$ and anti-IL-3r $\beta$ (Fig. 1) antibodies showed clear positive immunostaining in primary cortical neurons. These results suggest that this receptor is expressed in these cells. It is therefore reasonable to assume that these receptors are functional and able to transduce downstream signals. To investigate the possibility that IL-3 treatment produced activation of Jak2, ERK and Akt, lysates from cells treated with IL-3 for various times were subjected to Western blot analysis using anti-phospho-Jak2, -ERK, and -Akt antibodies to detect activated Jak2, ERK and Akt, respectively (Fig. $1 \mathrm{~B}$ and 1C). Duplicate blots were probed with antibodies recognizing total Jak2, ERK or Akt to verify equal protein loading in the samples. As shown in Fig. 1B, treatment with $5 \mathrm{nM}$ IL-3 led to increased phosphorylation of Jak2 within 10 minutes and this phosphorylation remained elevated for 60 minutes. Treatment with $5 \mathrm{nM}$ IL-3 also weakly activated Akt, an activation which was sustained for 20 minutes. Akt phosphorylation was fast for the first 30 minutes and after $2 \mathrm{~h}$ there is an increase that was sustained over $24 \mathrm{~h}$ in primary cortical neurons (Fig. 1D).

Also, ERK activation was evident at 5 minutes and was sustained for over 60 minutes. These results suggest that IL-3 receptors are functional and are able to transduce a signal in response to IL-3.

\section{Neuroprotective effect of IL-3 on neurons treated with A $\beta_{\text {I-40 }}$}

Several results suggest that aggregated $A \beta$ peptide, as well as the oligomeric forms of this peptide, are highly toxic for a variety of cultured primary neurons and neuronal cell lines. Cortical neurons were treated with different concentrations of the aggregated $A \beta$ peptide $\left(A \beta_{1-42}\right)$ for $24 \mathrm{~h}$. $A \beta$ was dose-dependently toxic (Fig. 2, panel A), causing up to $40 \%$ cell death at $25 \mu \mathrm{M}$.

To determine whether IL-3 protects neurons against $\mathrm{A} \beta$, we treated cells with increasing concentrations of IL-3 (0 - $10 \mathrm{nM}$ ) $30 \mathrm{~min}$ before the assay and maintained a $24 \mathrm{~h}$ exposure to aggregated $10 \mu \mathrm{M} \mathrm{A} \beta_{1-42}$ (Fig. 2, panel B). Our results show a dose-dependent reduction in $A \beta$ toxicity following IL-3 treatment, with a clear increase in cell survival at $10 \mathrm{nM}$ IL-3. IL-1 was used as a negative control, having no effect on $A \beta$ toxicity (Fig. 2, panel D). IL-3 alone had no effect on cortical neurons (Fig 2, panel C).

In order to define whether DNA fragmentation occurred in neuronal cultures treated with $A \beta$ in the presence or absence of IL-3, we searched by TUNEL staining. A high number of TUNEL-positive cells with shrunken nuclei and condensed chromatin, as indicated by arrows, were detected in the presence of $10 \mu \mathrm{M} \mathrm{A} \beta$, whereas the TUNELpositive cells were far fewer in neuron cells pre-treated with $5 \mathrm{nM}$ IL-3 before $10 \mu \mathrm{M} \mathrm{A} \beta$ treatment (Fig. $2 \mathrm{E}$ ).

We also proved that the neuroprotective effect on $A \beta$-neurotoxicity is very similar to that found with insulin treatment (Fig. 2F). This observation suggests that IL-3, similar to insulin may offer trophic support to neurons [21].

\section{PI3KIAkt participates in IL-3-induced neuroprotection}

Activation of Akt requires the phosphorylation of Thr-308 and Ser-473 in the Akt $\alpha$ molecule. In this study, phosphorylation of Ser-473 was used to evaluate the activation of Akt. In order to determine whether Akt activation participates in IL-3-induced neuroprotection we used a specific inhibitor of PI 3-kinase, LY2940002, which is highly 

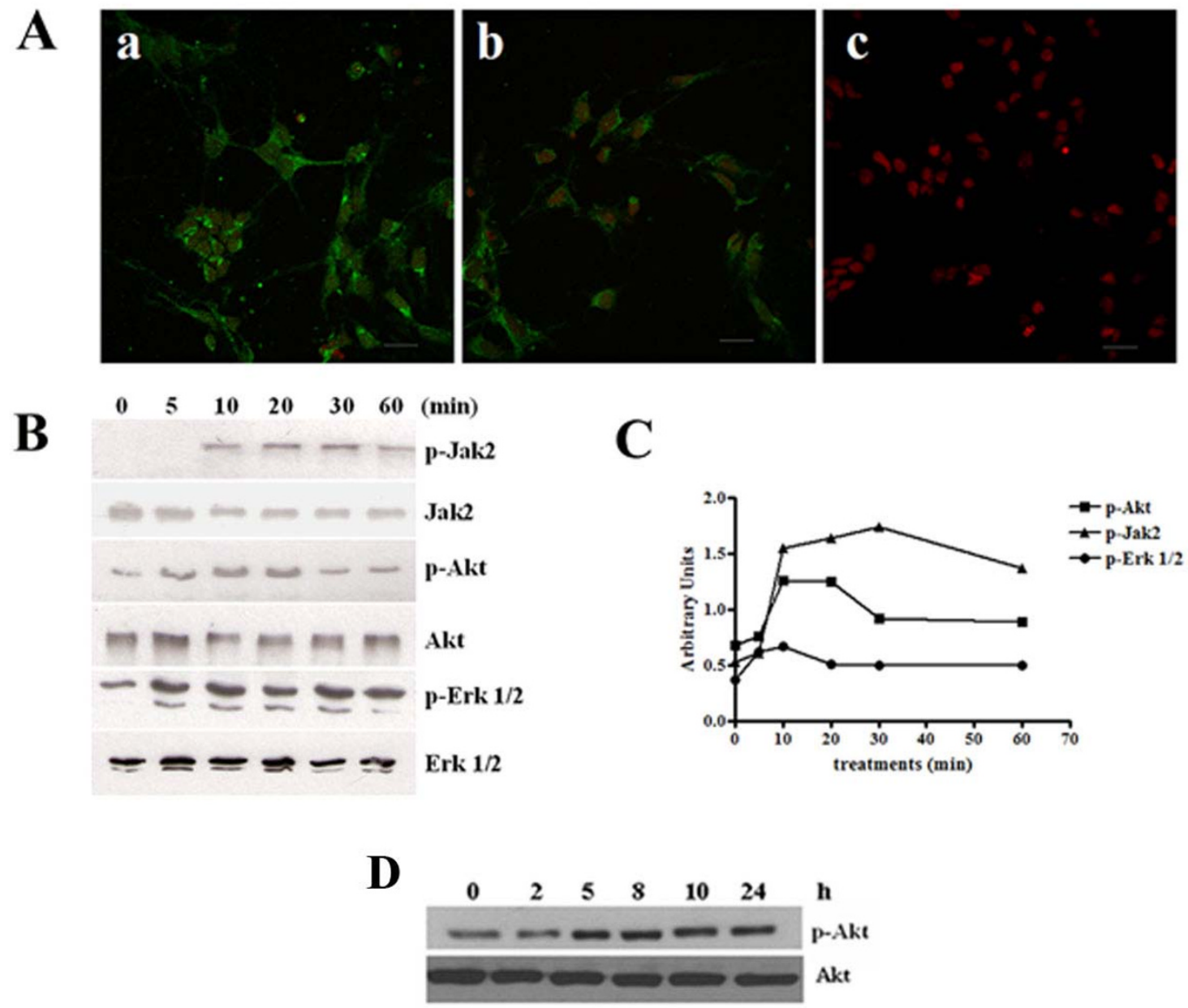

Figure I

Expression and activation of IL-3 receptors in cortical neurons. (A). Primary cortical neurons were incubated with anti-IL-3 $\alpha$ subunit (a), anti-IL-3 $\beta$ subunit (b) or without first (c) antibodies followed by incubation with a second antibody conjugated to FITC. Scale bar, $20 \mu \mathrm{m}$. (B). Western blot analysis shows Jak2, Akt and ERK phosphorylation in cortical neurons treated with 5 nM IL-3 for the indicated times. (C). Normalized densitometry scans of proteins panel B. (D). Western blot analysis shows Akt phosphorylation in cortical neurons treated with IL-3 for the indicated times. The results are representative of three separate experiments.

selective for PI 3-kinase inhibition. Cortical neurons were pre-treated with $50 \mu \mathrm{M}$ LY2940002 for $30 \mathrm{~min}$ prior to addition of $5 \mathrm{nM}$ IL-3. Cells were then exposed to $10 \mu \mathrm{M}$ $\mathrm{A} \beta$ and incubated for an additional $24 \mathrm{~h}$. These cells were used for Western blot, Tripan blue exclusion and MTT analysis. As shown by Western blot analysis (Figs. 3A and 3B), pre-treatment with LY2940002 blocked the IL-3evoked Akt activation. Also, LY2940002 blocked the BAD phosphorylation, a downstream effector of Akt, but had no effect on Jak 2 phosphorylation, which is a receptorassociated kinase upstream to Akt. As shown in Fig. 3C, pre-treatment of cells with LY2940002, totally abolished the protective effect of IL-3. The same results were obtained using $100 \mathrm{nM}$ Wortmannin (data not shown). These results suggest that IL-3-induced activation of Akt, by PI 3-kinase, was necessary for protection from $A \beta$ induced cell death.

\section{Participation of Jak2 in IL-3-induced protection}

The members of the family of Jak kinases are associated constitutively with a variety of cytokine receptors, including the IL-3 receptor. Upon binding of the specific ligand to its receptor, Jak kinases are rapidly activated, and their kinase activities are induced to regulate tyrosine phosphorylation of various effectors and to initiate activation of downstream signaling pathways. These pathways include 
A

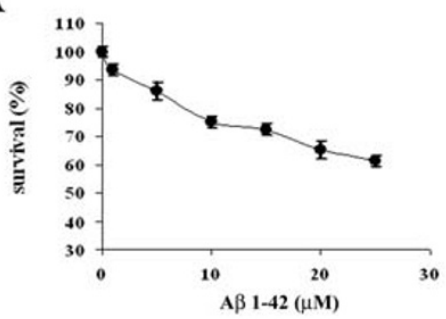

B

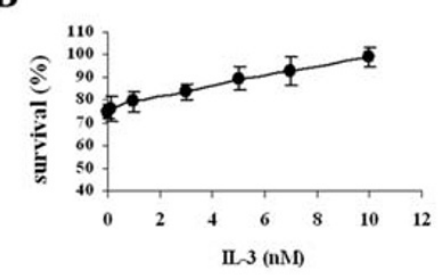

C

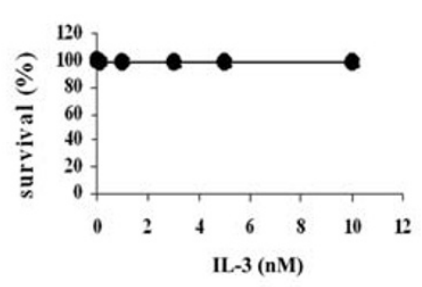

D

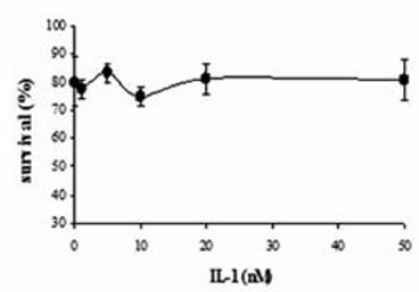

$\mathbf{E}$

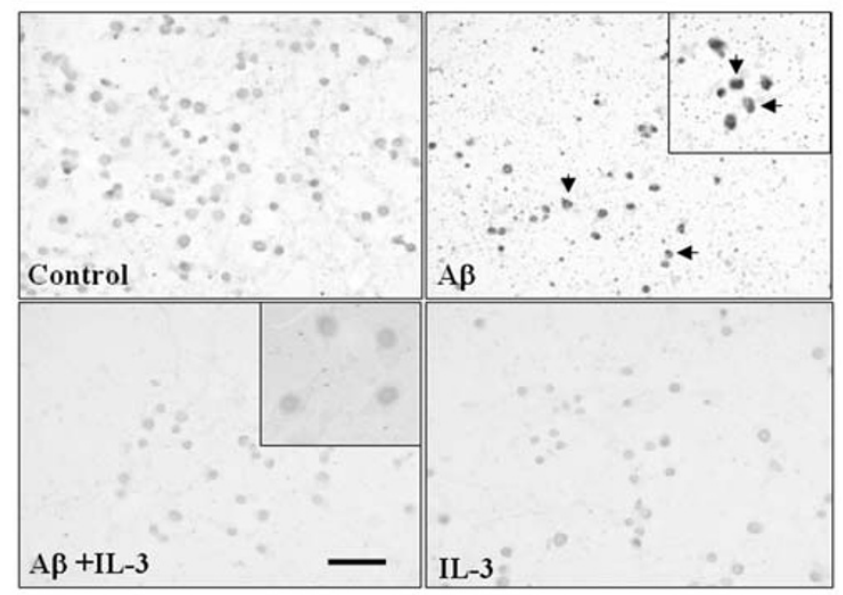

$\mathbf{F}$

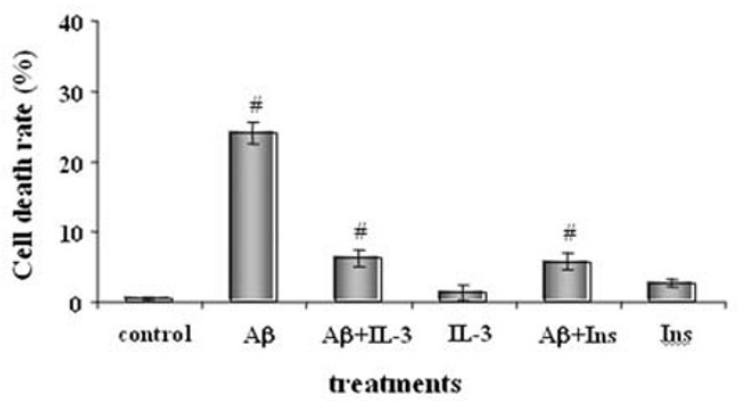

\section{Figure 2}

Effect of IL-3 on fibrillary A $\beta$-induced neurotoxicity in cortical neurons. MTT, Tripan blue and TUNEL staining analyses were used to determine cell death. (A). Cortical neurons were treated with different concentrations of $A \beta$ peptide for 24 $h$ at $37^{\circ} \mathrm{C}$. (B). Neurons were incubated with different concentrations of IL-3 and then treated with I0 $\mu M A \beta$. (C). Neurons were incubated with different concentrations of IL-3 in the absence of $A \beta$. (D). Neurons were incubated with different concentrations of IL-I and then treated with $10 \mu \mathrm{MA} \beta$. Data are mean \pm S.E. for three separate experiments performed in duplicate. (E). Cortical neurons were treated with $10 \mu \mathrm{M} \mathrm{A} \beta$ in the absence or presence of $5 \mathrm{nM} \mathrm{IL-} 3$ for $24 \mathrm{~h}$ at $37^{\circ} \mathrm{C}$. TUNEL-positive neurons were visualized by microscopy and the shrunken nuclei are indicating by arrows. (F). Primary cortical neurons were pre-treated with $5 \mathrm{nM} \mathrm{IL-3}$ or $100 \mu \mathrm{M}$ insulin for $30 \mathrm{~min}$, and then treated with $10 \mu \mathrm{A} \beta$ for $24 \mathrm{~h}$ at $37^{\circ} \mathrm{C}$. MTT and Tripan blue analyses were used to determine cell death. Data are means \pm S.E. for three separate experiments performed in duplicate. 
A

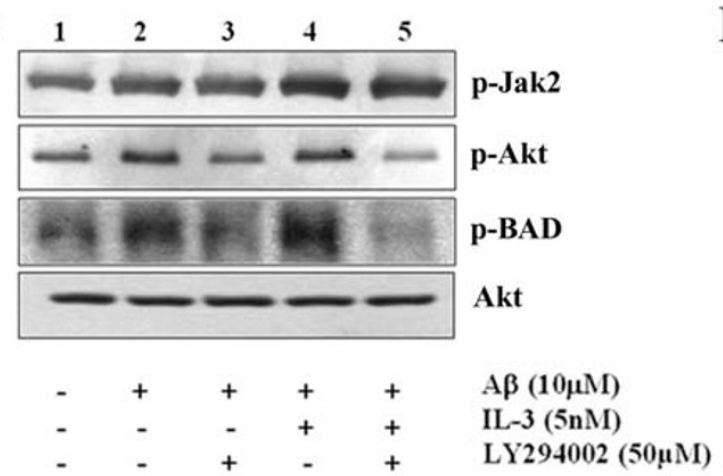

B

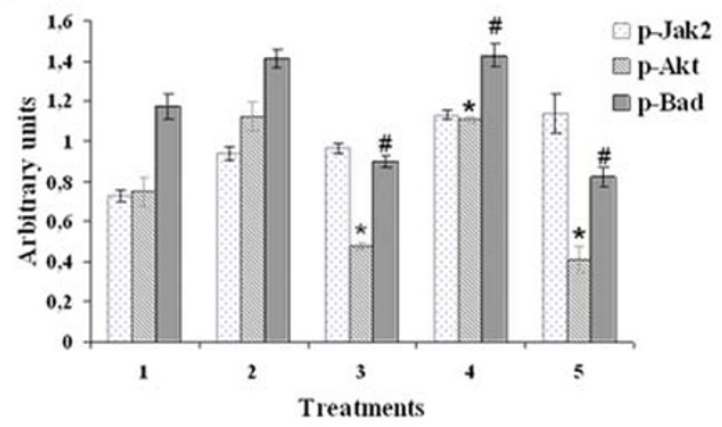

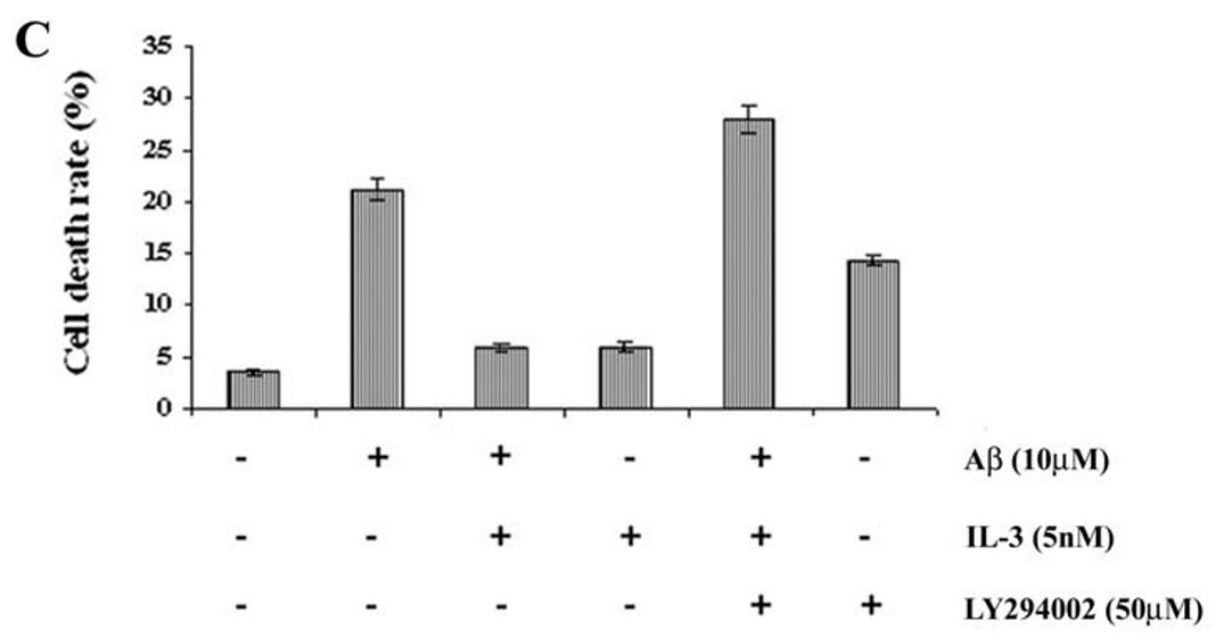

\section{Figure 3}

Inhibition of PI 3-kinase blocked Akt phosphorylation and IL-3 mediated neuroprotection against A $\beta$ toxicity. Primary cortical neurons were pre-treated with $50 \mu \mathrm{M}$ LY2940002 for $30 \mathrm{~min}$ before addition of $5 \mathrm{nM}$ IL-3. One hour after addition of growth factor, cells were then exposed to $10 \mu \mathrm{M} \mathrm{A} \beta$ and incubated for an additional $24 \mathrm{~h}$. Cells incubated with vehicle (PBS containing $\leq 0.1 \%$ DMSO $\mathrm{v} / \mathrm{v}$ ) and not exposed to IL-3 or A $\beta$ were defined as control cells. Then the cells were used for Western blot and viability analysis. (A) Western blot analysis using phosphorylation-specific antibodies (p-Jak2, p-Akt, and $p-B A D$ ), and total anti-Akt I antibodies. (B). Normalized densitometry scans of proteins (mean \pm SEM, *, \#, $p<0.05$ ). The student's t-test was used for the statistical analysis of significance of difference. (C). Neuronal death was determined by MTT colorimetric assay and Tripan blue exclusion. Data represent mean \pm SEM for three independent experiments (with a minimum of 4-5 wells per group for each experiment).

PI3K, MAPK, and NF-кB (nuclear factor-kappa B), leading to cell differentiation, survival and proliferation. To determine whether Jak2 kinase is implicated in IL-3-induced neuroprotection, we used AG490, a highly selective specific inhibitor of Jak2. Cortical neurons were pre-treated for 30 min with $20 \mu \mathrm{M}$ AG490 before addition of IL-3 and $\mathrm{A} \beta$ peptide. AG490 induced a decrease in Jak2 and Akt phosphorylation (Fig. 4A and 4B). Pre-treatment with AG490 totally abolished the protective effect of IL-3 (Fig. $4 \mathrm{C})$. These results suggest that IL-3 induce Jak2 activation, and that this activation is necessary for protection from $\mathrm{A} \beta$-induced death.

\section{Role of ERK in the neuroprotective action of IL-3}

Activation of ERK and Akt pathways has been shown to promote cell survival/proliferation after growth factor stimulation and to play a protective role. To investigate ERK involvement, we tested the effect of PD98059 on IL3-induced neuroprotection. PD98059 is a selective inhibitor of the MEK kinase pathway, kinase upstream of ERK. Cells were pre-treated with $20 \mu \mathrm{M}$ PD98059 for $30 \mathrm{~min}$ prior to addition of IL-3. After addition of IL-3, cells were exposed to $10 \mu \mathrm{M} \mathrm{A} \beta$ and incubated for an additional 24 h. Pre-treatment with PD98059 blocked IL-3-evoked ERK activation, but had no effect on Jak2 and Akt activation 
A

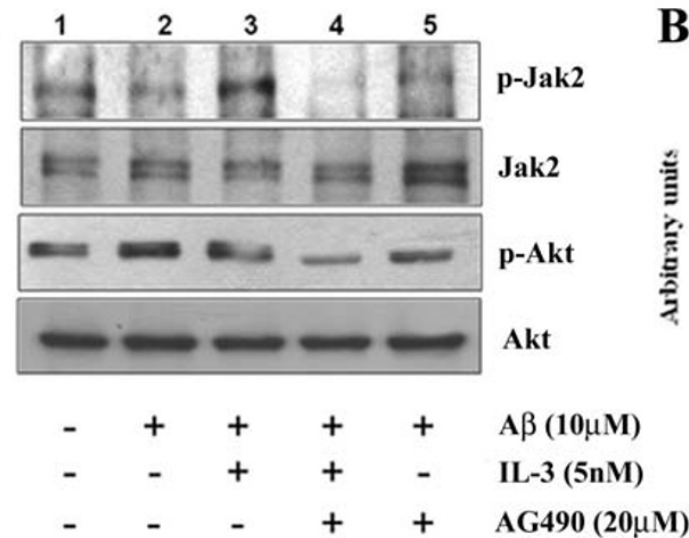

B

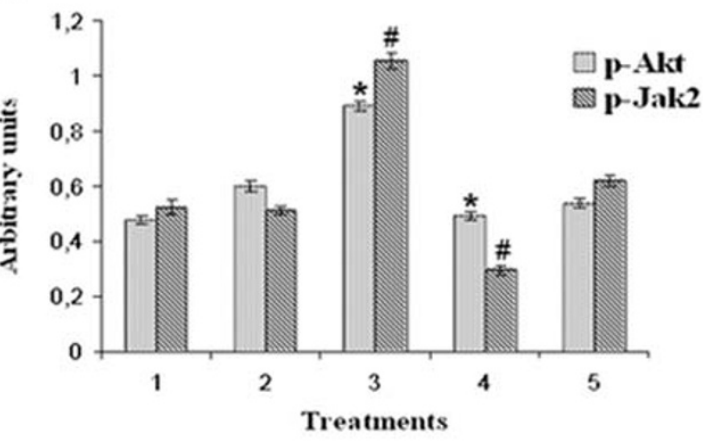

C

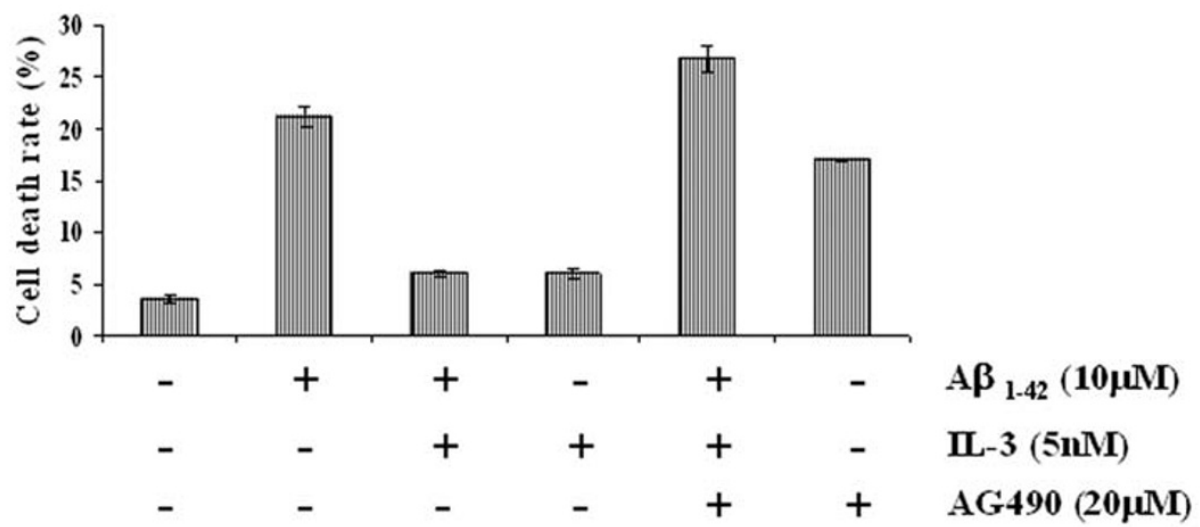

\section{Figure 4}

Inhibition of Jak2 kinase blocked Akt phosphorylation and neuronal survival by IL-3. Primary cortical neurons were pre-treated with $20 \mu \mathrm{M}$ AG490 for 30 min before addition of $5 \mathrm{nM}$ IL-3. One hour after addition of growth factor, cells were exposed to $10 \mu \mathrm{MA} \beta$ and incubated for an additional $24 \mathrm{~h}$. Cells incubated with vehicle (PBS containing $\leq 0.1 \% \mathrm{DMSO} v / \mathrm{v})$ and not exposed to IL-3 or A $\beta$ were defined as control cells. Then the cells were used for Western blot and viability analysis. (A) Western blot analysis using phosphorylation-specific antibodies (p-Jak2, and p-Akt), and total anti-Akt l and anti-Jak2 antibodies. (B). Normalized densitometry scans of proteins (mean $\pm \mathrm{SEM}, *$, \#, $p<0.05$ ). The student's t-test was used for the statistical analysis of significance of difference. (C). Neuronal death was determined by MTT colorimetric assay and Tripan blue exclusion. Data represent mean \pm SEM for three independent experiments (with a minimum of 4-5 wells per group for each experiment).

(Fig. 5A and 5B). Results are consistent with the notion that Jak2 is a kinase upstream of ERK, and these results therefore suggest that IL-3-evoked Akt activation is not dependent on ERK phosphorylation. Next, we evaluated the ability of IL-3 to promote cell survival in neurons treated with PD98059 for $24 \mathrm{~h}$. As shown in Fig. 5C, PD98059 did not alter the IL-3 effect on A $\beta$-induced cell death. The results suggest that IL-3 protected against A $\beta$ induced death by regulating Jak and PI3K/Akt pathways.

\section{IL-3 induces an increase in Bcl-2 expression}

A previous report [20] suggested that $A \beta$ is able to downregulate $\mathrm{Bcl}-2$ protein, a well-established anti-death protein in neurons. Several growth factors, among them IL-3, induce the $\mathrm{Bcl}-2$ expression. To investigate the role of $\mathrm{Bcl}$ 2 in the IL-3-induced protection, cells treated with $A \beta$ in the presence or absence of IL-3 were analyzed by Western blot analysis. As shown in Fig. 6, there was a decrease of Bcl-2 protein levels in cells treated with $10 \mu \mathrm{M} \mathrm{A} \beta$. Cells pre-treated with $5 \mathrm{nM}$ IL-3 1 h before addition of $A \beta$, presented no decrease in Bcl-2. This suggests that IL-3 is able to maintain $\mathrm{Bcl}-2$ protein levels similar to those in control cells in the presence of $A \beta$ peptide.

\section{Discussion}

It has been proposed that IL-3 has a neuroprotective role, but the mechanism has been poorly described. The data presented here provide strong evidence that IL-3 can act 
A

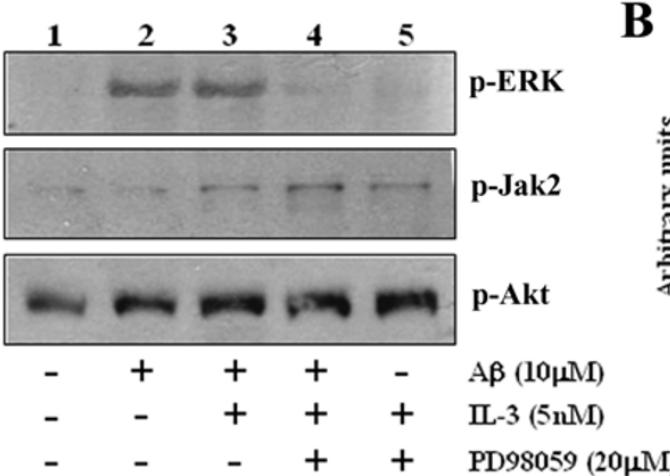

B

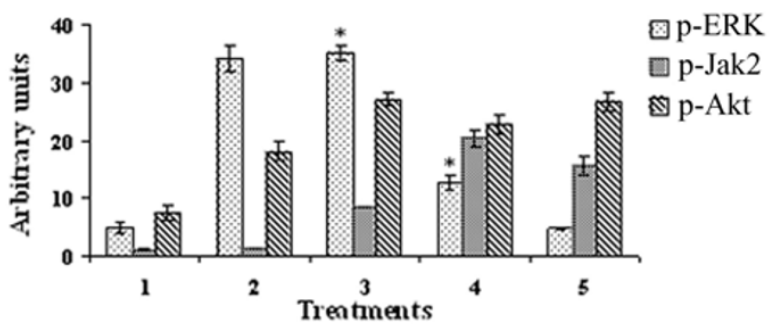

C

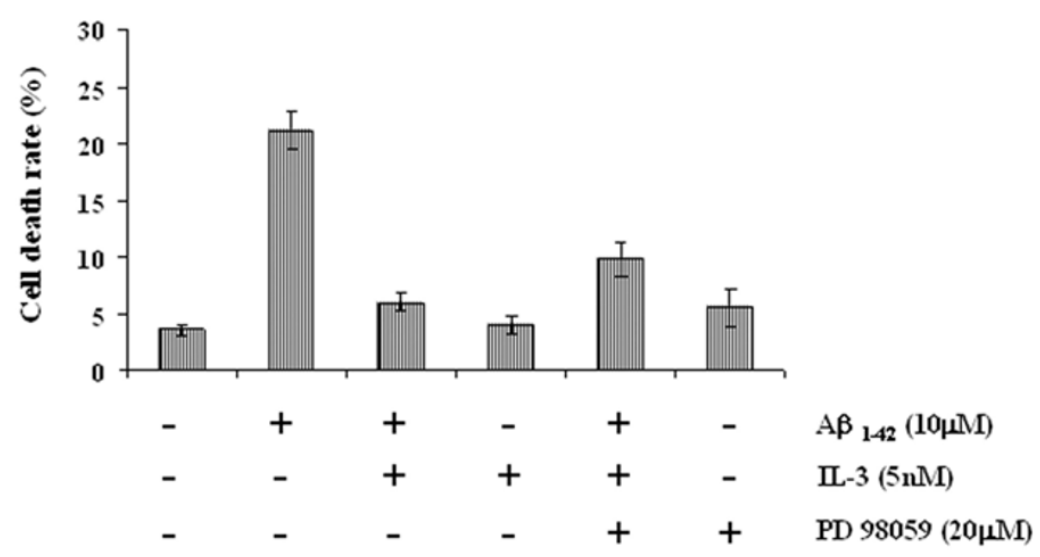

Figure 5

Effect of PD98059 on IL-3 mediated neuroprotection against A $\beta$ toxicity. Primary cortical neurons were pre-treated with $20 \mu$ M PD98059 for 30 min before addition of 5 nM IL-3. One hour after addition of interleukin, cells were exposed to 10 $\mu \mathrm{M} \mathrm{A} \beta$ and incubated for an additional $24 \mathrm{~h}$. Then the cells were used for Western blot and viability analysis. (A) Immunoblot analysis using phosphorylation-specific antibodies (p-ERK I/2, p-Jak2, and p-Akt). (B). Normalized densitometry scans of proteins (mean \pm SEM, * , \#, $p<0.05$ ). The student's t-test was used for the statistical analysis of significance of difference. (C). Neuronal death was determined by MTT colorimetric assay and Tripan blue exclusion. Data represent mean \pm SEM for three independent experiments (with a minimum of 4-5 wells per group for each experiment).

directly on neurons and activate neuronal survival pathways. We demonstrated that IL-3 is a potent inhibitor of neuronal death induced by $\mathrm{A} \beta_{1-42}$ exposure. These findings were complemented by kinase phosphorylation studies, including the use of specific inhibitors that identified which survival pathways are activated by IL-3.

Alzheimer's disease (AD) brain is characterized by the selective loss of synapses and neurons. The presence of amyloid plaques composed primarily of aggregated amyloid $\beta$-peptide (A $\beta), 40$ to 42 aminoacids in length, is thought to be the toxic agent in $\mathrm{AD}$ [22]. The mechanism by which $A \beta$ induces cell death or apoptosis is not yet clear. Previous authors have suggested that $A \beta$ downregulates survival protein, such as Bcl-2 [20]. Additionally, mutant presinilin 1 (PS1) of familial $\mathrm{AD}$, induces apopto- sis, downregulates the survival factor Akt/PKB, and affects several Akt/PKB downstream targets, including glycogen synthase kinase $3 \beta$ and $\beta$-catenin [23].

However, it has been reported that several factors, such as IGF-I, protect hippocampal neurons from $\mathrm{A} \beta$ toxicity. The initial signaling involved in this protection has been shown to involve both ERK and PI 3-kinase-dependent pathways. All these results strongly suggest that $A \beta$ downregulates the natural protective mechanism in neurons, and the activation of some growth factor receptor can protect neurons from $A \beta$-induced cell death by anti-apoptotic pathways activation.

Previous studies of IL-3 in the central nervous system demonstrated the expression of IL-3 mRNA in neurons of 

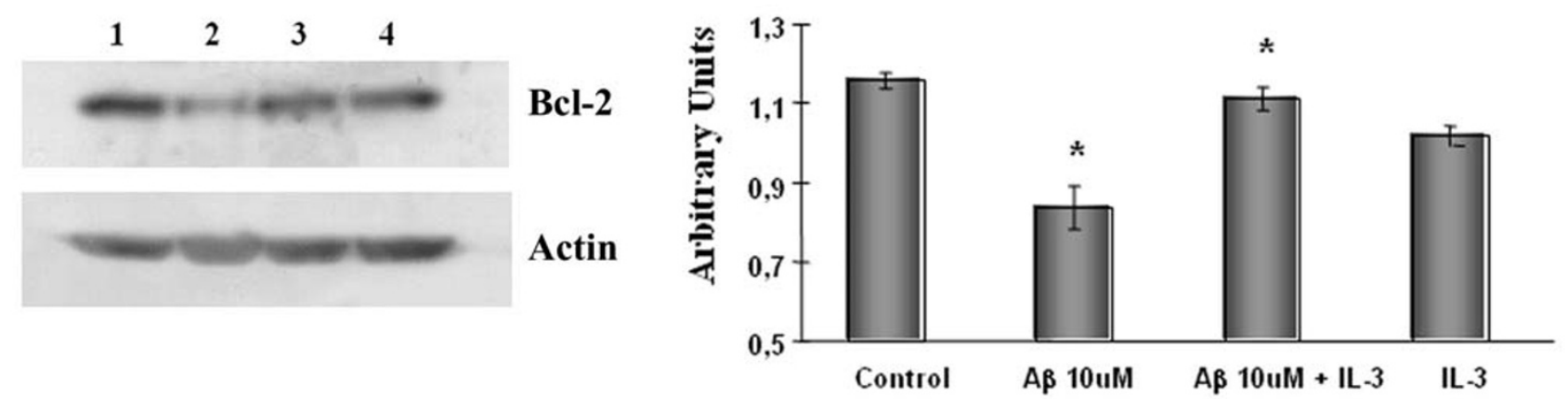

\section{Figure 6}

IL-3 induces an increase of Bcl-2 protein. Protein extracts from cortical neurons not exposed to IL-3 or A $\beta$, were defined as control cells (lane I), cells treated with I0 $\mu$ M A $\beta$ in the absence (lane 2) or presence (lane 3 ) of $5 \mathrm{nM} \mathrm{IL-3} \mathrm{and} \mathrm{cells} \mathrm{treated}$ with IL-3 (lane 4) were analyzed by Western blot using anti-Bcl-2 and anti-actin antibodies. Blots shown are from representative experiments.

the habenula, hippocampus, cerebral and enthorhinal cortices, and subiculum in normal mouse brain [4], and suggested endogenous IL-3 might be produced by certain neurons [12]. Functional IL-3 receptors are expressed in the central cholinergic neurons and contribute to some physiological roles such as the differentiation and maintenance of these neurons. Also, both hippocampus and cerebral cortex express IL-3r $\alpha$ and $\beta$ subunits [5].

We demonstrated that primary cortical neurons express IL-3r $\alpha$ and $\beta$ subunits. Biological response analyses confirmed the presence of functionally active IL-3 receptors, responsive to mouse IL-3 in cortical neurons. Binding of this cytokine to its receptor leads to the stimulation of classical signal transduction pathways, specifically the Jak/STAT pathway, the Ras/MAPK pathway, and the PI 3kinase/PKB pathway [24]. The data showed that IL-3 induced activation of these pathways in this cell type. In general there was a fast and transient increase of the phosphorylation of p-Jak2 and p-ERK. However, Akt phosphorylation was fast for the first 30 minutes and after $2 \mathrm{~h}$ there is an increase that was sustained over $24 \mathrm{~h}$ in primary cortical neurons.

The neuroprotective effect of IL-3 against the amyloid was studied by fragmented DNA using TUNEL staining, MTT and Tripan blue exclusion analysis. We demonstrated that IL-3 prevents $A \beta$-neurotoxicity. IL- 3 induces an increase in cell viability of more than $75 \%$ in cells treated with $A \beta$. Our results are consistent with other groups, which have reported that IL-3 has a functional role in some neurons. Some authors have demonstrated that the survival of sensory neurons was significantly supported by IL-3, which also stimulates their morphological differentiation [13]. IL-3 also attenuated neuronal damage caused by free radicals, which are known to be overproduced during and after brain ischemia. Furthermore, IL-3 was able to protect NGF-differentiated neurons from apoptotic cell death caused by NGF withdrawal [25].

We showed that this neuroprotective effect on $\mathrm{A} \beta$-neurotoxicity is similar to that found with insulin treatment. Direct actions of insulin on neurons and neuron-like cells have suggested it may offer trophic or growth factor support to these structures. In some in vitro systems, and in some in vivo models, a role for direct insulin support for regeneration has been suggested [21].

It has been proposed that IL-3 has a neuroprotective role, but no underlying biological mechanism has been identified. We showed that IL-3 protected against $A \beta$-induced cell death and activated Akt. A specific inhibitor of PI 3kinase blocked this activation and abolished protection of $A \beta$-induced cell death, indicating that activation of Akt was important for IL-3 protection. Activation of Akt protects cells from apoptotic signals such as growth factor withdrawal, cell cycle disruption, and cell detachment [26]. PI 3-kinase has been implicated in the regulation of cell survival in several cell types. In particular, PI 3-kinase is thought to be involved in IL-3-dependent survival, and that a region on the $\beta c$ receptor important for IL-3dependent survival is necessary for PI 3-kinase activation. Akt is activated by factors that stimulate PI 3-kinase activity in cells, such as thrombin, platelet-derived growth factor, and insulin [27]. Active Akt can promote cell survival in response to various death stimuli, including withdrawal from growth factors [10]. Here we demonstrated that Akt activity is induced rapidly by the cytokine IL-3 in cortical neurons and that activation of Akt by IL-3 is dependent on the PI 3-kinase activity. 
Akt was activated downstream from PI 3-kinase, resulting in the phosphorylation and inactivation of $\mathrm{BAD}$, a principal inducer of cell apoptosis. It has been demonstrated that activated Akt phosphorylates BAD, resulting in its sequestration by cytosolic $14-3-3$ proteins $[28,29]$ Because BAD binds to and inhibits the anti-apoptotic actions of $\mathrm{BCl}_{-\mathrm{XL}}$, the sequestration of $\mathrm{BAD}$ in the cytosol by 14-3-3 proteins results in enhanced survival. This signalling pathway has been shown to play an important role in neuronal development and survival [30].

We also provide evidence that $A \beta$-induced apoptosis is prevented through the IL-3 induced activation of Jak2. Our findings indicate that IL-3r activation induces Jak2 activation via tyrosine phosphorylation and that this initial event is followed by tyrosine phosphorylation of PI 3kinase and Akt serine phosphorylation as suggested by the inhibitory effect of AG-490 on the phosphorylation of both proteins. These results are consistent with those reported for hematopoietic cells, in which the kinase domain of Jak2 inhibits cell death and treatment with the Jak2 inhibitor AG-490 reduces phosphorylation of PI 3kinase, resulting in increased caspase 3 activity and Bax protein in acute myocardial infarction [31]. In addition, activation of neuronal erythropoietin receptors prevents apoptosis by triggering cross-talk between the signaling pathways of Jak2 and the nuclear factor- $\kappa \mathrm{B}$ (NF- $\kappa \mathrm{B}$ ) $[31,32]$.

Activation of ERK and Akt pathways have been shown to promote cell proliferation/survival after growth factor stimulation and to play a protective role. Activation of both ERK and Akt are important steps in cellular responses to a variety of extracellular stimuli [26]. However, we demonstrated that inactivation of the mitogenactivated protein kinase pathway by PD98059, a selective inhibition of mitogen-activated protein kinase/extracellular signal regulated kinase, did not affect IL-3-mediated survival, meaning that the Akt pathway is primarily involved and rendering ERK activation unnecessary for the IL-3-induced survival function. In contrast to our findings, in other cell systems, the inhibition of ERK activation with a dominant-negative MAPKK, suppresses IL-3dependent survival, in, for example, BaF3 cells [33].

The IL-3-induced targets important for cell survival, seem to be proteins of the anti-apoptotic $b c l-2$ gene family. Expression of $b c l-2$ and $b c l_{X L}$ is rapidly induced by IL-3 or activated Ras in multiple cell types [34,35]. We showed that cells treated with $\mathrm{A} \beta$ had decreased $\mathrm{Bcl}-2$ protein levels, consistent with some reports which suggested that $A \beta$ is able to downregulate Bcl-2 protein [20]. However, IL-3 is able to support $\mathrm{Bcl}-2$ protein levels in the presence of $\mathrm{A} \beta$ peptide. Overexpression of $b c l-2$ blocks apoptosis induced by IL-3 withdrawal in cell lines $[36,37]$. Bcl-2 is well estab- lished as an anti-death protein in neurons. Bcl-2 can avert survival factor deprivation-induced neuronal apoptosis in sympathetic cervical ganglia, in sensory primary neurons, and in continuous cell lines such as PC12 cells [38].

\section{Conclusion}

In summary, our data constitute the first experimental evidence of the role of IL-3 in neurodegeneration Alzheimer's type. We show that IL-3 prevents neuronal death induced by $\mathrm{A} \beta$ peptide and suggest that the specific pathways responsible include activation of PI 3-kinase and Jak2. IL-3 was also able to induce an increase of the antiapoptotic protein, $\mathrm{Bcl}-2$.

\section{Methods \\ Cell Cultures}

Cortical neurons obtained from 16-day-old mice embryos were prepared as previously described [39]. Briefly, embryos were removed from the dams at E16 and placed into Hank's balanced salt solution (1 mM HEPES, pH 7.4, $8 \mathrm{mM} \mathrm{NaCl}, 0.27 \mathrm{mM} \mathrm{KCl}, 0.28 \mathrm{mM}$ glucose, $0.02 \mathrm{mM}$ $\mathrm{KH}_{2} \mathrm{PO}_{4}$ ). Embryonic day 1 was defined as the day of conception established by the presence of a vaginal plug. Embryos were dissected and minced well with scissors. Tissue was dissociated with $0.25 \%$ trypsin at $37^{\circ} \mathrm{C}$ for 15 min and then by mechanical grinding, with a sterile, firepolished glass Pasteur pipette, in Minimum Essential Media (MEM) supplemented with $10 \%$ FBS. The cells were collected by centrifugation and resuspended in a serumfree medium consisting of neurobasal medium (NB) supplemented with B27 and $0.5 \mathrm{mM}$ L-glutamine. Neurons were grown at $37^{\circ} \mathrm{C}$ in humidified $5 \% \mathrm{CO} 2$ atmosphere for 7-10 days prior to experimentation. Cortical cells were plated onto coverslips or in $35-\mathrm{mm}$ plastic dishes precoated with polylysine $(10 \mu \mathrm{g} / \mathrm{ml})$.

\section{Preparation of the $A \beta$ fibrils}

The $A \beta_{1-42}$ peptide (purchased from Chiron Corporation; Emereville, CA, USA) was subjected to aggregation as described [40]. The A $\beta$ fibrils were concentrated by centrifugation $(20.000 \times \mathrm{g}$ for $30 \mathrm{~min})$ and resuspended at 1 $\mathrm{mg} / \mathrm{ml}$ in PBS (137 mM NaCl, $2.7 \mathrm{mM} \mathrm{KCl}, 10 \mathrm{mM}$ $\mathrm{Na}_{2} \mathrm{HPO}_{4}, 2 \mathrm{mM} \mathrm{KH} \mathrm{PO}_{4}$ ). A $\beta$ concentration was evaluated using the BCA protein assay (Pierce, Rockford, IL. USA) [41].

\section{Immunofluorescence}

Cortical neurons were fixed in $4 \%$ paraformaldehyde in PBS for $20 \mathrm{~min}$, washed in several changes of PBS for 10 min, permeabilized in $0.3 \%$ Triton X-100 in PBS for 15 min and incubated overnight at $4{ }^{\circ} \mathrm{C}$ with anti-IL-3r $\alpha$ or anti-IL-3r $\beta$, antibodies (Santa Cruz Biotechnology, Sta. Cruz, CA, USA). After a wash in PBS (three washes, for 15 min each), cells were incubated in fluorescein isothiocyanate-conjugated goat anti-mouse IgG or fluorescein iso- 
thiocyanate-conjugated goat anti-rabbit IgG secondary antibodies, for $1 \mathrm{~h}$ at room temperature. Fluorescent images were obtained using a Zeiss Axioscope II fluorescence microscope. (Carl Zeiss, Göttingen, Germany).

\section{Western blot analysis}

Cortical neurons were plated at $1 \times 10^{6} \mathrm{cells} / \mathrm{cm}^{2}$ on 35 $\mathrm{mm}$ dishes. Cultured cells were exposed to $\mathrm{A} \beta$ fibrils and/ or interleukins for $24 \mathrm{~h}$, for the described time periods. For the experiments with inhibitors to different kinases, cortical neurons were pre-incubated in the presence or absence of $50 \mu \mathrm{M}$ LY2940002 (PI3K inhibitor), $100 \mathrm{nM}$ Wortmannin (PI3K inhibitor), $20 \mu \mathrm{M}$ AG490 (Jak2 inhibitor) or $20 \mu \mathrm{M}$ PD98059 (MEK inhibitor) for $1 \mathrm{~h}$ and then treated for $24 \mathrm{~h}$ with $\mathrm{A} \beta$ and/or IL-3. Afterwards, cells were homogenized in RIPA buffer (50 mM Tris, $\mathrm{pH} 7.5,150$ $\mathrm{mM} \mathrm{NaCl}, 5 \mathrm{mM}$ EDTA, 1\% NP-40, 0.5\% sodium deoxycholate, $0.1 \%$ SDS, $100 \mu \mathrm{g} / \mathrm{ml} \mathrm{PMSF}, 2 \mu \mathrm{g} / \mathrm{ml}$ aprotinin, 2 $\mu \mathrm{M}$ leupeptin, and $1 \mu \mathrm{g} / \mathrm{ml}$ pepstatin) and the protein concentration was determinated by the Bradford analysis [42]. Proteins extracts were resolved by SDS-PAGE ( $60 \mu \mathrm{g}$ per lane) in a $10 \%$ polyacrylamide gel [43] and transferred to immobilon (Millipore, Bedford, MA, USA). After blocking with $5 \%$ non-fat dry milk the membranes were incubated with primary antibodies (Akt, p-Akt, Jak2, pJak2, ERK1/2, p-ERK 1/2, Bcl-2, actin, p-BAD antibodies from Santa Cruz Biotechnology, Sta. Cruz, CA, USA) in a $1 \%$ BSA in PBS overnight at $4{ }^{\circ} \mathrm{C}$. After washing, the membranes were incubated with horseradish peroxidase-conjugated secondary antibodies (Sigma Chemical Co, St. Louis, Mo, USA) for $1 \mathrm{~h}$ at room temperature. The antibody blots were developed by chemiluminescence (Amersham, Arlington Heights, IL, USA).

\section{Viability assays}

Primary cortical neurons were seeded in 96-well plates coated with polylysine $10 \mu \mathrm{g} / \mathrm{ml}$. Then cells were treated with the $10 \mu \mathrm{M} \beta$-amyloid fibrils with or without $5 \mathrm{nM}$ IL3 or $100 \mathrm{nM}$ insulin, and in the absence or presence of inhibitors $50 \mu \mathrm{M}$ LY2940002, $100 \mathrm{nM}$ Wortmannin (PI3K inhibitors), $20 \mu \mathrm{M}$ AG490 (Jak2 inhibitor), and $20 \mu \mathrm{M}$ PD98059 (MEK inhibitor), as described previously. After $24 \mathrm{~h}$ incubation, the mitochondrial activity was measured by the modified 3- [4,5-dimethylthiazol 2-yl]-2,5 diphenyltetrazolium bromide (MTT) assay [44]. This involves determining mitochondrial dehydrogenase activity in intact cells by incubation for $4 \mathrm{~h}$ at $37^{\circ} \mathrm{C}$ with MTT $(10 \mu \mathrm{l}$ de $5 \mathrm{mg} / \mathrm{ml}$ MTT solution per well). The reaction was stopped by addition of cell lysis buffer ( $50 \%$ dimethylformamide and $20 \%$ SDS, pH 7.4). $\Delta$ A values at $550-650 \mathrm{~nm}$ were determined the following day, using an automatic microtiter plate reader (Metertech $\Sigma 960$ ) and the results were expressed as a percentage of control. The cell viability was also assessed with Trypan blue exclusion.
To measure DNA fragmentation, cells were fixed in freshly prepared $4 \%$ paraformaldehyde for $20 \mathrm{~min}$ at room temperature and incubated with blocking solution $\left(3 \% \mathrm{H}_{2} \mathrm{O}_{2}\right.$ in methanol), then permeabilized in $0.1 \%$ Triton X-100, $0.1 \%$ sodium citrate on ice for $2 \mathrm{~min}$. Terminal deoxynucleotidyl transferase-mediated dUTP nick-end labeling (TUNEL) was performed using the In situ Cell Death Detection, POD as described by the manufacturer (Roche, Basel, Switzerland).

\section{Statistical analysis}

Data were expressed as the mean \pm SEM of the values from the number of experiments performed in triplicate as indicated in the corresponding figures. MTT and Tripan blue data and histograms were evaluated statistically by using the student's t-test, with $\mathrm{P}<0.05$ considered significant.

\section{Abbreviations}

The abbreviations used are: IL-3, Interleukin 3; $A \beta, \beta$-amyloid; JAKs, Janus kinases; STAT, signal transducers and activators of transcription; MAPK, mitogen-activated protein kinase; ERK, extracellular signal-regulated protein kinases; PI 3k, phosphatidylinositol 3-kinase; PKB, protein kinase $\mathrm{B} ; \mathrm{AD}$, Alzheimer's disease; $\mathrm{PBS}$, phosphate buffered saline; BSA, bovine serum albumin; MTT, 3- [4,5dimethylthiazol 2-yl]-2,5 diphenyltetrazolium bromide; TUNEL, terminal deoxynucleotidyl transferase-mediated dUTP nick-end labeling.

\section{Authors' contributions}

AZ participated in the study, designing the protocol for the laboratory investigation and coordination of the manuscript. CO participated in the study design and coordination of the manuscript. LM participated in the design of the study. IC and RM conceived the study and participated in its design and helped to draft the manuscript. All authors read and approved the final manuscript.

\section{Acknowledgements}

This work was supported by grants from the Millennium Institute CBB, FONDECYT Grants 1990994, 1050198 and 1020155, DID2003-0I, DID2004-60 and MECESUP AUS 0006. AZ and CO were supported by CONICYT doctoral Fellowship.

\section{References}

I. Arai K, Lee F, Miyajima A, Miyatake S, Arai N, Yokota T: Cytokines: coordinators of Immune and Inflammatory Responses. Annu Rev Biochem 1990, 59:783-836.

2. Morstyn G, Burgess AW: Hemopoietic growth factors: a review. Cancer Res 1988, 48(20):5624-5637.

3. Nicola NA: Hemopoietic cell growth factors and their receptors. Annu Rev Biochem 1989, 58:45-77.

4. Farrar WL, Vinocour M, Hill JM: In situ hybridization histochemistry localization of interleukin-3 mRNA in mouse brain. Blood 1989, 73(I): I37-40.

5. Tabira T, Chui DH, Fan JP, Shirabe T, Konishi Y: Interleukin-3 and interleukin-3 receptors in the brain. Ann N Y Acad Sci 1998, 840: $107-116$.

6. Rauch MC, Brito M, Zambrano A, Espinoza M, Perez M, Yanez A, Rivas $\mathrm{Cl}$, Slebe JC, Vera JC, Concha II: Differential signalling for 
enhanced hexose uptake by interleukin (IL)-3 and IL-5 in male germ cells. Biochem J 2004, 38 I (Pt 2):495-50I.

7. Vilanova LT, Rauch MC, Mansilla A, Zambrano A, Brito M, Werner E, Alfaro V, Cox JF, Concha II: Expression of granulocyte-macrophage colony stimulating factor (GM-CSF) in male germ cells: GM-CSF enhances sperm motility. Theriogenology 2003, 60(6): 1083-1095.

8. Zambrano A, Noli C, Rauch MC, Werner E, Brito M, Amthauer R, Slebe JC, Vera JC, Concha II: Expression of GM-CSF receptors in male germ cells and their role in signaling for increased glucose and vitamin C transport. J Cell Biochem 200I, 80(4):625-634.

9. Appel K, Buttini M, Sauter A, Gebicke-Haerter PJ: Cloning of rat interleukin-3 receptor beta-subunit from cultured microglia and its mRNA expression in vivo. I Neurosci 1995, I 5(8):5800-5809.

10. Dudek H, Datta SR, Franke TF, Birnbaum MJ, Yao R, Cooper GM, Segal RA, Kaplan DR, Greenberg ME: Regulation of neuronal survival by the serina threonine protein kinase Akt. Science 1997, 275(5300):66I-665.

II. Frei K, Bodmer S, Schwerdel C, Fontana A: Astrocytes of the brain synthesize interleukin 3-like factors. J Immunol 1985, I 35(6):4044-4047.

12. Konishi Y, Kamegai M, Takahashi K, Kunishita T, Tabira T: Production of interleukin-3 by murine central nervous system neurons. Neurosci Lett 1994, I 82(2):27|-274.

13. Moroni SC, Rossi A: Enhanced survival and differentiation in vitro of different neuronal populations by some interleukins. Int J Dev Neurosci 1995, I 3(1):4I-49.

14. Kamegai M, Konishi Y, Tabira T: Trophic effect of granulocytemacrophage colony-stimulating factor on central cholinergic neurons in vitro. Brain Res 1990, 532(I-2):323-325.

15. Wen TC, Tanaka J, Peng H, Desaki J, Matsuda S, Maeda N, Fujita H, Sato K, Sakanaka M: Interleukin 3 prevents delayed neurona deathin the hippocampal CAI field. J Exp Med 1998, 1 88(4):635-649.

16. Maccioni RB, Muñoz JP, Barbeito L: The molecular bases of Alzheimer's disease and other neurodegenerative disorders. Arch Med Research 200I, 32(5):367-38I.

17. Maccioni RB, Otth C, Concha II, Muñoz JP: The protein kinase cdk5: structural aspects, roles in the neurogenesis and involvement in Alzheimer's pathology. European J Biochem 200I, 268(6): I5I8-I527.

18. Yankner BA, Caceres A, Duffy LK: Nerve growth factor potentiates the neurotoxicity of beta amyloid. Proc Natl Acad Sci USA 1990, 87(22):9020-9023.

19. LaFerla FM, Tinkle BT, Bieberich CJ, Haudenschild CC, Jay G: The Alzheimer's $A \beta$ peptide induces neurodegeneration and apoptotic cell death in transgenic mice. Nature Genet 1995, 9(I):21-30.

20. Paradis E, Douillard H, Koutroumanis M, Goodyer C, LeBlanc A: Amyloid $\beta$ peptide of Alzheimer's disease downregulates Bcl-2 and upregulates Bax expression in human neurons. J Neurosci 1996, I 6(23):7533-7539.

21. Fernyhough P, Willars GB, Lindsay RM, Tomlinson DR: Insulin and insulin-like growth factor $I$ enhance regeneration in cultured adult rat sensory neurons. Brain Res 1993, 607(I-2): I 17-124.

22. Iversen LL, Mortishire-Smith RJ, Pollack SJ, Shearman MS: The toxicity in vitro of beta-amyloid protein. Biochem J $1995,3 \mathrm{I} \mathrm{I(Pt}$ I): $1-16$.

23. Weihl CC, Ghadge GD, Kennedy SG, Hay N, Miller RJ, Roos RP Mutant presenilin-I induces apoptosis and downregulates Akt/PKB. J Neurosci 1999, 19(13):5360-5369.

24. Guthridge MA, Stomski FC, Thomas D, Woodcock JM, Bagley C], Berndt MC, Lopez AF: Mechanism of activation of the GM-CSF, IL-3, and IL-5 family of receptors. Stem Cells 1998, I6(5):30I-3I3.

25. Kannan Y, Moriyama M, Sugano T, Yamate J, Kuwamura M, Kagaya A, Kiso Y: Neurotrophic action of interleukin 3 and granulocytemacrophage colony-stimulating factor on murine sympathetic neurons. Neuroimmunomodulation 2000, 8(3): $132-14 \mid$.

26. Wei $W$, Wang $X$, Kusiak JW: Signaling events in amyloid $\beta$-peptide-induced neuronal death and Insulin-like growth factor I protection. J Biol Chem 2002, 277(20):17649-17656.

27. Franke TF, Kaplan DR, Cantley LC: PI3K: downstream AKTion blocks apoptosis. Cell 1997, 88(4):435-437.
28. Datta SR, Dudek H, Tao X, Masters S, Fu H, Gotoh Y, Greenberg ME: Akt phosphorylation of BAD couples survival signals to the cell-intrinsic death machinery. Cell I997, 9 I(2):23 I-4I.

29. Del Peso L, Gonzalez-Garcia M, Page C, Herrera R, Nunez G: Interleukin-3-induced phosphorylation of BAD through the protein kinase Akt. Science 1997, 278(5338):687-689.

30. Buonanno A, Fischbach GD: Neuregulin and ErbB receptor signaling pathways in the nervous system. Curr Opin Neurobiol 200I, I I (3):287-296.

31. Digicaylioglu M, Lipton SA: Erythropoietin-mediated neuroprotection involves cross-talk between Jak2 and NF-kappaB signalling cascades. Nature 200I, 4I 2(6847):64I-647.

32. Shaw S, Bencherif M, Marrero MB: Janus kinase 2 , an early target of alpha 7 nicotinic acetylcholine receptor-mediated neuroprotection against Abeta-(I-42) amyloid. J Biol Chem 2002, 277(47):44920-44924.

33. DeGroot RP, Coffer PJ, Koenderman L: Regulation of proliferation, differentiation and survival by the IL-3/IL-5/GM-CSF receptor family. Cell Signal 1998, I0(9):619-628.

34. Kinoshita T, Yokota T, Arai K, Miyajima A: Suppression of apoptotic death in hematopoietic cells by signaling through the IL-3/GM-CSF receptors. EMBO J 1995, I 4(2):266-275

35. Leverrier Y, Thomas J, Perkins GR, Mangeney M, Collins MK, Marve $\mathrm{J}$ : In bone marrow derived Baf-3 cells, inhibition of apoptosis by IL-3 is mediated by two independent pathways. Oncogene 1997, 14(4):425-430.

36. Lin EY, Orlofsky A, Wang HG, Reed JC, Prystowsky MB: AI, a Bcl2 family member, prolongs cell survival and permits myeloid differentiation. Blood 1996, 87(3):983-992.

37. Ito T, Deng X, Carr B, May WS: Bcl-2 phosphorylation required for anti-apoptosis function. I Biol Chem 1997 , 272(12): ||67|-II673.

38. Songyang Z, Baltimore D, Cantley LC, Kaplan DR, Franke TF: Interleukin 3-dependent survival by the Akt protein kinase. Proc Natl Acad Sci USA 1997, 94(2 I): I I345- I I 350.

39. Ma W, Maric D, Li B, Hu Q, Andreadis JD, Grant GM, Liu QY, Shaffer KM, Chang YH, Zhang L, Pancrazio J], Pant HC, Stenger DA, Barker $\mathrm{JL}$ : Acetylcholine stimulates cortical precursor cell proliferation in vitro via muscarinic receptor activation and MAP kinase phosphorylation. European I of Neurosci 2000, I 2(4): 1227-1240.

40. Alvarez A, Toro R, Cáceres A, Maccioni RB: Inhibition of tau phosphorylating protein kinase cdk5 prevents $\beta$-amyloid-induced neuronal death. FEBS Letters 1999, 459(3):42I-426.

4I. Smith PK, Krohn RI, Hermanson GT, Mallia AK, Gartner FH, Provenzano MD, Fujimoto EK, Goeke NM, Olson BJ, Klenk DC: Measurement of protein using bicinchoninic acid. Anal Biochem 1985, I50(I):76-85

42. Bradford MM: A rapid and sensitive method for the quantitation of microgram quantitaties of protein utilizing the principle of protein-dye binding. Anal Biochem 1976, 72:248-254.

43. Laemmli UK, Quittner SF: Maturation of the head of bacteriophage T4. IV. The proteins of the core of the tubular polyheads and in vitro cleavage of the head proteins. Virology 1974 , 62(2):483-499

44. Mosmann T: Rapid colorimetric assay for cellular growth and survival: Application to proliferation and cytotoxicity assays. J Immunol Methods 1983, 65(I-2):55-63.

Publish with Bio Med Central and every scientist can read your work free of charge

"BioMed Central will be the most significant development for disseminating the results of biomedical research in our lifetime. "

Sir Paul Nurse, Cancer Research UK

Your research papers will be:

- available free of charge to the entire biomedical community

- peer reviewed and published immediately upon acceptance

- cited in PubMed and archived on PubMed Central

- yours - you keep the copyright
BioMedcentral 